\title{
Competition, Innovation, Risk-Taking, and Profitability in the Chinese Banking Sector: An Empirical Analysis Based on Structural Equation Modeling
}

\author{
Ti Hu${ }^{1}$ and $\mathrm{Chi} \mathrm{Xie}^{1,2}$ \\ ${ }^{1}$ College of Business Administration, Hunan University, Hunan, China \\ ${ }^{2}$ Center of Finance and Investment Management, Hunan University, Hunan, China
}

Correspondence should be addressed to Chi Xie; xiechi@hnu.edu.cn

Received 23 August 2016; Accepted 3 October 2016

Academic Editor: Chris Goodrich

Copyright (C) 2016 T. Hu and C. Xie. This is an open access article distributed under the Creative Commons Attribution License, which permits unrestricted use, distribution, and reproduction in any medium, provided the original work is properly cited.

\begin{abstract}
We introduce a new perspective to systematically investigate the cause-and-effect relationships among competition, innovation, risk-taking, and profitability in the Chinese banking industry. Our hypotheses are tested by the structural equation modeling (SEM), and the empirical results show that (i) risk-taking is positively related to profitability; (ii) innovation positively affects both risk-taking and profitability, and the effect of innovation on profitability works both directly and indirectly; (iii) competition negatively affects risk-taking but positively affects both innovation and profitability, and the effects of competition on risk-taking and profitability work both directly and indirectly; (iv) there is a cascading relationship among market competition and bank innovation, risk-taking, and profitability.
\end{abstract}

\section{Introduction}

Managing a bank is a complex process that involves interactions of numerous factors. Among all of these factors, risktaking and profitability are the most two important indicators of bank performance.

Innovation is regarded as an important factor which influences both risk-taking and profitability, because bank's innovation activities improve the efficiency of the screening and monitoring of borrowers, which then reduces risktaking and enhances profitability. Besides, financial innovation generates technology-based products which have several advantages, such as high returns and low risk.

Competition is widely accepted as an important factor that influences all of innovation, risk-taking, and profitability. Specifically, it is generally acknowledged that market competition changes a bank's operating conduct, which subsequently influences bank risk-taking and profitability. For example, the market competition stimulates bank's innovation activities and makes bank more efficient in screening and monitoring borrowers, which in turn affects bank risktaking and profitability.
Though there are lots of empirical works about the causeand-effect relationships in banking, most of them focus on one-on-one relationships between the factors. We contribute to the literature by clearly presenting a technical framework of structural equation modeling (SEM) applied in the banking industry and systematically investigating the relationships among competition, innovation, risk-taking, and profitability. Accordingly, our purpose is to reveal the interactional mechanism of these four factors through the application of SEM.

We select the Chinese banking industry as a sample, which is impacted by financial innovation in many aspects, such as organization, management, production, and business [1]. Furthermore, the Chinese banking industry has undergone comprehensive reform since 1979, and, as a consequence, the market structure has also been transformed [2].

\section{Literature Review}

2.1. Competition and Profitability. The structure-conductperformance (SCP) hypothesis from traditional industrial 
organization theory states that a firm's performance is determined by its business strategy which is influenced by industry structure [3]. Furthermore, the SCP hypothesis posits that because of collusion and domination, firms earn higher profits in a concentrated market than in a competitive market. In other words, there is a positive relationship between market concentration and firm profitability [4]. With respect to the banking industry, existing literature provides lots of empirical supports for the SCP hypothesis. Bhatti and Hussain test the SCP hypothesis in the context of Pakistan's banking industry and their result supports the SCP hypothesis [5]. Kamau and Were investigate the driving factors of bank performance in Kenya during 1997-2011 and find that the source of superior performance is structure/collusive power [6]. Uddin and Suzuki empirically assess a negative relationship between competition and profitability by using banking sector data from Bangladesh [7]. Tan and Floros investigate the relationship among market concentration, profitability, and risktaking in the Chinese banking industry during the period from 2003 to 2009 and testify a negative relationship between competition and profitability [8].

2.2. Competition and Risk-Taking. A standard view of banking supervision is that competition is detrimental to bank stability. On the one hand, competition erodes a bank's franchise value which is equivalent to the cost of bankruptcy and encourages bank to pursue risky policies, such as lowering capital levels and softening the terms of loans, which increase nonperforming loans and result in credit risk [9]. On the other hand, a bank will select safe policies, which contribute to the stability of the entire banking system, to protect its franchise value when the market competition is restrained [10]. Another view argues that banks' policies influence the behavior of borrowers, which in turn change bank risk-taking [11]. Specifically, restrained competition results in a high borrowing cost (i.e., interest rates being charged on loans), which possibly raise the credit risk of borrowers due to moral hazard issues [12]. For example, because of the information asymmetries in the credit business, borrowers can conceal their credit condition and payback ability, while banks are always at a disadvantage with respect to acquiring sufficient borrower information. Martinez-Miera and Repullo propose a model to illustrate the effect of competition on bank risk-taking and find that two effects working in opposite directions generate an unclear net effect on risk-taking and that the intensities of these two effects vary with the level of competition [13].

2.3. Competition and Innovation. The relationship between market competition and innovation is a primary focus of industrial organization theory. Schumpeter first states that market competition discourages innovation by diminishing monopoly rents and large firms are able to afford more capital for innovation activities [14]. On the contrary, some researchers assert that the Schumpeter hypothesis is not comprehensive and that there are more incentive factors in a competitive market than in a monopoly market [15]. Increased competition encourages innovation activities because firms in a competitive market attempt to escape competition and obtain monopoly profits [16]. Aghion et al. propose a theoretical model and confirm that two effects vary with competition and produce opposing results; thus the net effect of competition on innovation is unclear [17].

2.4. Innovation and Profitability. The efficiency hypothesis $(\mathrm{EH})$ posits that the bank profitability depends on the bank's degree of efficiency, whereas the bank's degree of efficiency is affected by its financial innovation activities [18]. That is to say, innovation improves bank technology, which then increases bank efficiency and enhances bank profitability. Moreover, Allen et al. find that improving a bank's technology enhances its quality of assets [19]. In addition, financial innovation generates new forms of bank products, such as Internet banking, mobile banking, telephone banking, ATMs, and POS networks, which provide relative high returns and low cost advantages that enhance bank profitability [20-22].

2.5. Innovation and Risk-Taking. Chen states that a bank's innovation activities improve the efficiency of the screening and monitoring borrowers and eventually reduce the quantity of nonperforming loans and the bank's credit risk [23]. Schaeck and Cihák propose that great efficiency will translate into reduced likelihood of bank default and enhanced stability [24]. However, Norden et al. claim that whether innovation is beneficial or not depends on why and how it is used by banks [25]. If innovation is employed to improve risk measurement and control, such as the screening and monitoring borrowers, it contributes to bank stability. However, if the innovation supported by banks is mainly for the purpose of achieving high profits, it encourages banks' risk-taking behaviors and leads to bank failure. Hou et al. find a positive relationship between technical efficiency and risktaking behaviors of Chinese commercial banks [26].

2.6. Risk-Taking and Profitability. The capital asset pricing model (CAPM) provides the first coherent framework for interpreting how the risk of an investment affects its expected return and depicts that the expected return is calculated by adding the risk free interest rate to the product of the investment's beta and the expected market risk premium [27]. The investment's beta is always positive; thus there is a positive relationship between market risk and expected return. A commercial bank must manage its assets through investments, and, in this sense, the bank can be perceived as an investor. Given that the risk appetites of bank managers determine the level of bank risk-taking, if most of a bank's managers are risk seekers, they will be willing to make risky decisions to obtain high returns. In other words, there is a positive relationship between bank risk-taking and profitability [28].

\section{Model Description}

SEM is a collection of procedures that tests hypothesized relationships among observed variables and is often related to 


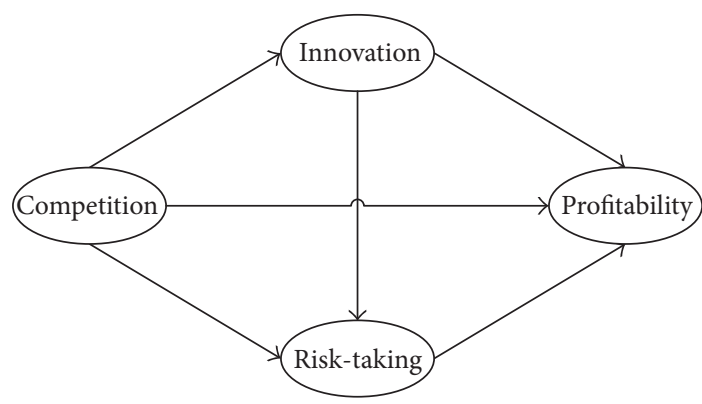

FIgURe 1: A hypothetical path model.

causal modeling [29]. It is regarded as a blending of confirmatory and exploratory analyses that is capable of representing and detecting the complex interactions of several factors [30].

Thus, we use the structural equation modeling (SEM) to systematically test the cause-and-effect relationships among competition, innovation, risk-taking, and profitability.

3.1. Path Model. The path model involves hypothesized cause-and-effect relationships among variables. These relationships are usually based on theoretical and empirical evidences from existing literature. Figure 1 illustrates the hypothesized cause-and-effect relationships among competition, innovation, risk-taking, and profitability. Competition is exogenous, because it is affected by administration policies rather than bank operating strategies. Innovation, risktaking, and profitability are endogenous.

Generally, an exogenous variable is always only a cause, but an endogenous variable can be a cause and/or an effect [31]. For example, innovation and risk-taking are both the causes of profitability and the effects of competition. The direct effect of a causal variable on an affected variable is denoted by the arrowed path, and the coefficient (direct effect) of each path is similar to a regression coefficient. The indirect effect of a causal variable is estimated as the product of the chain of direct effects, and the net effect is the sum of all direct and indirect effects.

In this scenario, competition is hypothesized to have one direct effect and three indirect effects on profitability. The indirect effects are mediated by innovation and risktaking, and the indirect paths are competition-innovationprofitability, competition-risk-taking-profitability, and competition-innovation-risk-taking-profitability, respectively. Innovation and risk-taking constitute the intermediate part of the indirect paths, indicating a cascading relationship among competition, innovation, risk-taking, and profitability.

3.2. Measurement Model. The measurement model is employed to quantify linkages between latent variables and observed variables.

Latent variable is a conceptual variable that is not directly observed but inferred from other observed variables. In our model, competition, innovation, risk-taking, and profitability are all regarded as latent variables.
Observed variables represent a specific latent variable in the form of a linear combination. The selection of observed variables must consider validity and reliability. Validity is the accuracy of an observed variable for representing a latent variable, and reliability is consistency and stability of an observed variable for representing a latent variable.

The measurement model of the exogenous variable is defined as follows:

$$
X=\Lambda_{x} \Theta+\Delta,
$$

where $X$ is a vector of the observed exogenous variables $x ; \Theta$ is a vector of the exogenous latent variables $\theta ; \Lambda_{x}$ is a matrix of factor loadings $\lambda_{x}$, relating $x$ to $\theta ; \Delta$ is a vector of the measurement errors $\delta$.

In our paper, competition is defined as $\theta$ and measured by concentration ratio $\left(x_{1}\right), \mathrm{HHI}\left(x_{2}\right)$, and Boone index $\left(x_{3}\right)$. Hence, (1) is expressed as follows:

$$
\left[\begin{array}{l}
x_{1} \\
x_{2} \\
x_{3}
\end{array}\right]=\left[\begin{array}{l}
\lambda_{x 1} \\
\lambda_{x 2} \\
\lambda_{x 3}
\end{array}\right] \theta+\left[\begin{array}{l}
\delta_{1} \\
\delta_{2} \\
\delta_{3}
\end{array}\right] .
$$

Similarly, the measurement model of the endogenous variable is defined as follows:

$$
Y=\Lambda_{y} H+E,
$$

where $Y$ is a vector of observed endogenous variables $y ; H$ is a vector of endogenous latent variables $\eta ; \Lambda_{y}$ is a matrix of factor loadings $\lambda_{y}$, relating $y$ to $\eta ; E$ is a vector of the measurement errors $\varepsilon$.

We define (i) innovation as $\eta_{1}$, which is represented by technology gap ratio $\left(y_{1}\right)$ and cost efficiency $\left(y_{2}\right)$; (ii) risktaking as $\eta_{2}$, which is represented by nonperforming loans ratio $\left(y_{3}\right)$, risk-weighted assets ratio $\left(y_{4}\right)$, and $Z$-score $\left(y_{5}\right)$; and (iii) profitability as $\eta_{3}$, which is represented by return on assets $\left(y_{6}\right)$, return on equity $\left(y_{7}\right)$, and net interest margin $\left(y_{8}\right)$. Hence, (3) is expressed as follows:

$$
\left[\begin{array}{l}
y_{1} \\
y_{2} \\
y_{3} \\
y_{4} \\
y_{5} \\
y_{6} \\
y_{7} \\
y_{8}
\end{array}\right]=\left[\begin{array}{ccc}
\lambda_{y 1} & 0 & 0 \\
\lambda_{y 2} & 0 & 0 \\
0 & \lambda_{y 3} & 0 \\
0 & \lambda_{y 4} & 0 \\
0 & \lambda_{y 5} & 0 \\
0 & 0 & \lambda_{y 6} \\
0 & 0 & \lambda_{y 7} \\
0 & 0 & \lambda_{y 8}
\end{array}\right]\left[\begin{array}{l}
\eta_{1} \\
\eta_{2} \\
\eta_{3}
\end{array}\right]+\left[\begin{array}{l}
\xi_{1} \\
\xi_{2} \\
\xi_{3} \\
\xi_{4} \\
\xi_{5} \\
\xi_{6} \\
\xi_{7} \\
\xi_{8}
\end{array}\right] .
$$

3.3. Structural Regression Model. The structural regression (SR) model combines the path and measurement models and is the most general kind of core model widely applied in SEM to take measurement errors of observed variables into account. The general form of SR model is

$$
H=P H+\Gamma \Theta+Z,
$$




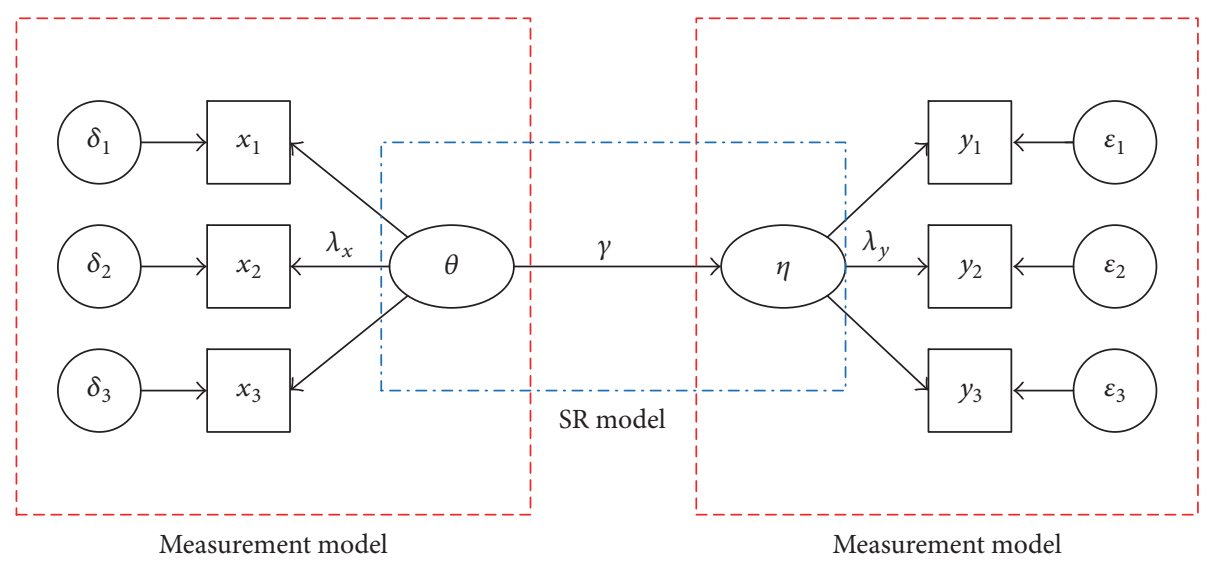

Figure 2: A simple form of SEM model.

TABLE 1: Market shares of sample banks.

\begin{tabular}{lccccccccccc}
\hline & 2004 & 2005 & 2006 & 2007 & 2008 & 2009 & 2010 & 2011 & 2012 & 2013 & 2014 \\
\hline Deposit & 0.81 & 0.78 & 0.77 & 0.74 & 0.73 & 0.72 & 0.70 & 0.70 & 0.69 & 0.67 & 0.66 \\
Loan & 0.76 & 0.73 & 0.71 & 0.70 & 0.68 & 0.69 & 0.68 & 0.68 & 0.67 & 0.66 & 0.65 \\
\hline
\end{tabular}

This table reports the market share of sample banks in both deposit and loan markets.

where $P$ is a matrix of path coefficients $\rho$, which describes the relationships among endogenous latent variables, $\Gamma$ is a matrix of path coefficients $\gamma$ that describes the linear effects of exogenous variables on endogenous variables, and $Z$ is a vector of the measurement errors $\zeta$.

Figure 2 illustrates a simple form of SEM. The central part is a structural regression model, and both left and right parts are measurement models.

In our paper, (5) is expressed as

$$
\left[\begin{array}{l}
\eta_{1} \\
\eta_{2} \\
\eta_{3}
\end{array}\right]=\left[\begin{array}{ccc}
0 & 0 & 0 \\
\rho_{21} & 0 & 0 \\
\rho_{31} & \rho_{32} & 0
\end{array}\right]\left[\begin{array}{l}
\eta_{1} \\
\eta_{2} \\
\eta_{3}
\end{array}\right]+\left[\begin{array}{l}
\gamma_{1} \\
\gamma_{2} \\
\gamma_{3}
\end{array}\right] \theta+\left[\begin{array}{l}
\zeta_{1} \\
\zeta_{2} \\
\zeta_{3}
\end{array}\right]
$$

3.4. Model Assessment. We follow Lam and Maguire and choose four basic indices to assess model fit [32]:

(i) The chi-square test, which is based on the test statistic $\chi^{2}$ and is only applicable in an overidentified model, that is, when $\mathrm{df}>0$

(ii) The root mean square error of approximation (RMSEA): a value range from 0.05 to 0.08 which indicating a reasonable approximation and a value $\geq$ 0.1 suggesting a poor fit

(iii) The standardized root mean square residual (SRMR): the SRMR $<0.10$ which is considered a good model fit

(iv) Joreskog-Sorbom goodness of fit index (GFI): The GFI which ranges from 0 to 1.0 with 1.0 indicating the best fit

\section{Data and Indicators}

4.1. Data. We test the hypothesis with the financial statement data from 14 listed commercial banks in China, namely, Bank of China, Industrial and Commercial Bank of China, China Construction Bank, Agricultural Bank of China, Bank of Communications, China CITIC Bank, China Merchants Bank, China Minsheng Bank, Industrial Bank, China Everbright Bank, Hua Xia Bank, China Guangfa Bank, Ping An Bank, and Shanghai Pudong Development Bank. All the relevant data is obtained from the China Statistical Yearbook and the annual reports of the banks from 2004 to 2014. These 14 banks account for nearly $70 \%$ share in both the deposit and loan markets (see Table 1) [33].

4.2. Indicators of Profitability. We select return on assets (ROA), return on equity (ROE), and net interest margin (NIM) to measure bank profitability.

ROA is the ratio of net profit to average total asset, which reflects the ability of a bank to generate profits by using its asset.

ROE is the ratio of net profit to shareholder equity, which reflects the ability of a bank to generate profits by using investment.

NIM is the ratio of net interest income to the bank's interest-earning assets, which reflects the profitability of the bank's credit business.

4.3. Indicators of Risk-Taking. Bank risk-taking is the risk resulting from banks' policies. We uses nonperforming loan (NPL) ratio, risk-weighted asset ratio, and $Z$-score to measure bank risk-taking. 
Nonperforming loan (NPL) is the loan that is in default or close to being in default, and the nonperforming loan ratio is the ratio of NPL to total loan.

Risk-weighted asset ratio is the ratio of risk-weighted asset to total asset, which measures bank risk-taking through capital constraint. The value of the risk-weighted assets can be calculated by dividing the sum of core capital and supplementary capital by capital adequacy ratio.

$Z$-score is a function of bank's return on asset (ROA), capital adequacy ratio (CAR), and the standard deviation of the bank's return on asset.

$$
Z=\frac{\mathrm{ROA}+\mathrm{CAR}}{\sigma(\mathrm{ROA})} .
$$
is [34]

The greater the $Z$-score is, the lower the bank's risk-taking

4.4. Indicators of Innovation. In order to measure bank innovation, we employ the cost efficiency (CE) and the technology gap ratio (TGR) and construct bank's cost function to examine bank's ability to minimize costs via innovation. Because the cost function describes the relationship between outputs and inputs, the set of estimated parameters reflects the state of technology and a parallel shift of the cost curve refers to the technical change triggered by innovation.

Figure 3 illustrates the technical change by using a simple paradigm with two inputs $\left(X_{1}, X_{2}\right)$ and one output $(Q)$ for two banks. Because the available technology of banks varies over time, there are two annual cost frontiers corresponding to $t=1$ and $t=2$. Given that the level of output is unchanged, the cost frontier represents the minimum cost curve based on available technology. The dashed line which envelops cost frontiers is the minimum cost curve over the whole period or metafrontier. The distance between the metafrontier and the cost frontier is defined as the technology gap, which measures the difference between the current available technology level and the optimal technology level. Battese et al. introduce metafrontier approach to measure technical change by constructing a cost function [35]. Figure 3 demonstrates that if Bank $\mathrm{I}$ is located at point $\mathrm{D}$, its cost inefficiency is OC/OD at time $t=1$ and $\mathrm{OB} / \mathrm{OD}$ at time $t=2$; and technology gap is OA/OC at time $t=1$ and OA/OB at time $t=2$. Similarly, if Bank II is located at point $\mathrm{H}$, its cost inefficiency is $\mathrm{OG} / \mathrm{OH}$ at time $t=1$ and $\mathrm{OF} / \mathrm{OH}$ at time $t=2$; and technology gap is $\mathrm{OE} / \mathrm{OG}$ at time $t=1$ and OE/OF at time $t=2$.

The cost efficiency represents the ratio of the minimum cost on the annual cost frontier to the bank cost for a certain level of output, and the technology gap ratio represents the ratio of the minimum cost on the metafrontier to that on the cost frontier for a certain level of output. The cost efficiency equals 1 when bank operates on the annual cost frontier, which means there is no inefficiency. Because the metafrontier is invariably below the cost frontier, the value of the technology gap ratio is bounded between 0 and 1 , where the latter is reached when bank operates on the metafrontier. Innovation generates technical improvement and consequently increases the value of cost efficiency and technology gap ratio.

Following Bos and Schmiedel and Bos et al., we initially employ the Stochastic Frontier Analysis (SFA) to estimate the cost frontiers in each year and then use a linear program to obtain the metafrontier [36, 37].

We express total cost as TC, output as $Q$, price of output as $p$, input as $x$, and price of input as $w$. Thus, total cost is defined as follows:

$$
\mathrm{TC}=w x
$$

Because $x$ is a function of $w$ and $Q,(8)$ is expressed as follows:

$$
\mathrm{TC}_{i t}=f\left(w_{i t}, Q_{i t}, z_{i t}\right) e^{v_{i t}+u_{i t}},
$$

where the subscript $i$ refers to a bank, subscript $t$ refers to a sample year, $z_{i t}$ denotes the control variable, and $v_{i t}$ denotes the random noise assumed to be i.i.d. $N\left(0, \sigma_{v}{ }^{2}\right), u_{i t}$ denotes the inefficiency term assumed to be i.i.d. $N\left(0, \sigma_{u}{ }^{2}\right)$ and is independent from $v_{i t}$. The cost efficiency is obtained as follows:

$$
\mathrm{CE}_{i t}=\left[\exp \left(-u_{i t}\right)\right]
$$

We model bank production by employing the intermediation approach because of banks' financial intermediary role. The intermediation approach regards banks' fixed asset, labor, and funds as inputs $\left(x_{i t}\right)$ and loans and investments as outputs $\left(Q_{i t}\right)$. The total cost consists of capital cost, operating cost, and labor cost (see Table 2) [38].

We obtain the metafrontier by enveloping the cost frontiers and utilize the parameter estimates for the cost frontiers $f_{i}$. The technology gap is calculated by fitting the minimum cost metafrontier $f_{\text {meta }}$ as follows:

$$
\begin{array}{ll}
\min & \text { Distance }=\sum_{i=1}^{N} \sum_{t=1}^{T}\left[f_{i}\left(w_{i t}, y_{i t}, z_{i t}\right) e^{v_{i t}+u_{i t}}-f_{\text {meta }}\left(w_{i t}, y_{i t}, z_{i t}\right) e^{v_{i t}+u_{i t}}\right]^{2}, \\
\text { s.t. } & f_{i}\left(w_{i t}, y_{i t}, z_{i t}\right) e^{v_{i t}+u_{i t}} \geq f_{\text {meta }}\left(w_{i t}, y_{i t}, z_{i t}\right) e^{v_{i t}+u_{i t}},
\end{array}
$$

where $N$ is the total number of banks and $T$ is the total number of sample years.
The constraint condition in (11) means that the total cost on the metafrontier is less than or equal to the total cost on 


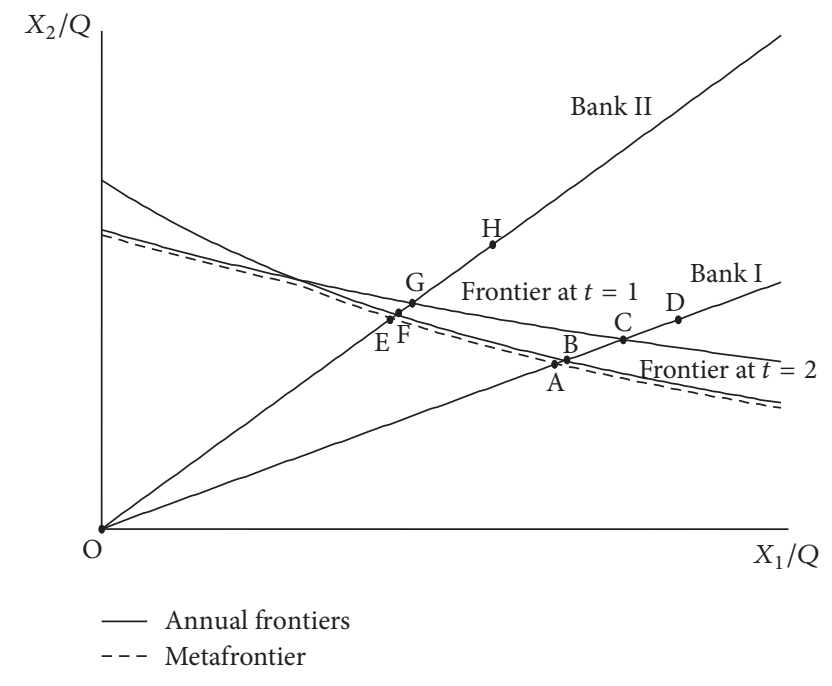

Figure 3: Cost efficiency and technology gap ratio.

TABLE 2: Definitions of variables.

\begin{tabular}{|c|c|}
\hline Variable & Definition \\
\hline \multicolumn{2}{|l|}{ Total cost } \\
\hline Capital cost & Interest expense \\
\hline Operating cost & $\begin{array}{l}\text { Business and management cost, loss of } \\
\text { impairment of asset }\end{array}$ \\
\hline Labor cost & Employee salary and welfare \\
\hline \multicolumn{2}{|l|}{ Input } \\
\hline Labor price & $\begin{array}{l}\text { The ratio of cash payments for salaries } \\
\text { and staff expenses to amount of labor }\end{array}$ \\
\hline Fixed assets price & $\begin{array}{l}\text { The ratio of depreciation to net fixed } \\
\text { asset }\end{array}$ \\
\hline Funds price & $\begin{array}{l}\text { The ratio of interest expense to the } \\
\text { sum of customer deposit and } \\
\text { borrowed fund }\end{array}$ \\
\hline \multicolumn{2}{|l|}{ Output } \\
\hline Investment & $\begin{array}{l}\text { Financial assets at fair value through } \\
\text { profit or loss, available-for-sale } \\
\text { financial assets, held-to-maturity } \\
\text { investment, receivables-bond } \\
\text { investment }\end{array}$ \\
\hline Loan & $\begin{array}{l}\text { Personal loan, corporate loan, other } \\
\text { loans }\end{array}$ \\
\hline
\end{tabular}

This table reports the definitions and measurements of the variables in (9).

the annual cost frontier. As a result, the TGR is calculated as follows:

$$
\mathrm{TGR}_{i t}=\frac{f_{\text {meta }}\left(w_{i t}, y_{i t}, z_{i t}\right)}{f_{i}\left(w_{i t}, y_{i t}, z_{i t}\right)}, \quad 0<\mathrm{TGR}_{i t} \leq 1 .
$$

4.5. Indicators of Competition. We employ concentration ratio (CR), Herfindahl-Hirschman Index (HHI), and Boone index to measure competition.

Concentration ratio (CR) is a reverse indicator of competition and measures the total market share occupied by a specified number of the largest banks in the industry. We select $\mathrm{CR}_{4}$ to measure competition, because the four biggest banks, namely, Bank of China, Industrial and Commercial Bank of China, China Construction Bank, and Agricultural Bank of China, dominate the Chinese banking industry.

Herfindahl-Hirschman Index (HHI) is a commonly accepted measure of market concentration. The value of the $\mathrm{HHI}$ is calculated by squaring the market share of all banks in the industry and then summing the result.

Boone index is an indicator of competition proposed by Boone and associates performance with the difference in efficiency [39]. Usually, banks achieve different performance due to their different efficiencies. As market competition increases, the differences among bank performances become more obvious. That is to say, market competition has a reallocation effect on banks which enhances the performance of efficient banks and weakens the performance of inefficient banks. Boone model is expressed as follows:

$$
\pi_{i t}=\alpha+\beta \ln \left(C_{i t}\right),
$$

where the subscript $i$ refers to a bank, subscript $t$ refers to a sample year, $\pi_{i t}$ denotes the profit, and $C_{i t}$ denotes the marginal cost. Because the marginal cost cannot be directly observed, we use the average cost as a proxy [40].

With respect to the banking industry, the profit $\left(\pi_{i t}\right)$ can be calculated by subtracting the operating expense from the operating income, and the average cost $\left(C_{i t}\right)$ can be calculated by dividing the operating expense by the profits. The operating income is composed of net interest income, net fees, commission income, gains or losses from changes in fair values, and investment income; and the operating expense contains business taxes and surcharges, general and administrative expenses, and impairment losses on assets.

$\beta$ refers to Boone index which is always negative because it expresses the decline in profits caused by cost inefficiencies. The larger $\beta$ in absolute value is, the stronger competition is.

To allow for time variation and capture $\beta$ at every single unit of time, we introduce $d_{k t}$ as a time dummy variable, where $d_{k t}=1$ if $k=t$ and $d_{k t}=0$ otherwise.

$$
\pi_{i t}=\alpha_{i}+\sum_{k=1}^{T} \beta_{k 1} d_{k t} \ln \left(c_{i t}\right)+\sum_{k=1}^{T-1} \beta_{k 2} d_{k t}+u_{i t}
$$

where $T$ is the total number of sample years and $u_{i t}$ is the random error term.

\section{Hypothesis and Results}

5.1. Hypotheses. Although a comprehensive reform is placed to facilitate the liberalization, the monetary authority still plays a leading role in Chinese banking industry. The market structure mainly resulted from the policies of the authority, rather than market discipline. Thus, we obtain several hypotheses for the empirical work.

(i) The SCP hypothesis assumes that bank profitability is influenced by market structure or competition. A concentrated market indicates collusion and monopoly, which make a bank earn high profits. In other words, a bank in a concentrated market has a high profitability. Thus, we hypothesize that competition is detrimental to bank profitability. 
Hypothesis 1. Competition has a negative relationship with bank profitability in the Chinese banking industry.

(ii) Competition has both positive and negative effects on bank risk-taking at the same time. The intensities of these two effects vary with competition; thus the relationship between competition and bank risk-taking is unclear. We hypothesize that competition is negatively related to risktaking, considering that the Chinese banking industry is highly concentrated and bank's market interest rate primarily results from administration policies rather than market discipline.

Hypothesis 2. Competition has a negative relationship with bank risk-taking in the Chinese banking industry.

(iii) Banks in a concentrated market can afford more capital for innovation activities due to the monopoly rents, but a competitive market provides more incentive factors for bank innovation than in a concentrated market. In Chinese banking industry, the domination of banks mainly resulted from the policies of the authority, rather than market discipline. Therefore, we hypothesize that competition is positively related to banks' innovation activities.

Hypothesis 3. Competition has a positive relationship with bank innovation in the Chinese banking industry.

(iv) The efficiency hypothesis (EH) states that bank profitability depends on its efficiency, which is affected by bank's innovation activities. In addition, new technologybased products generated by innovation also enhance profitability. Therefore, we hypothesize that innovation activities are beneficial to bank profitability.

Hypothesis 4. Innovation has a positive relationship with bank profitability in the Chinese banking industry.

(v) Though innovation can trigger technical progress and efficiency improvement, whether innovation is beneficial or not depends on why and how it is used by banks. Based on the empirical work about Chinese commercial banks, we hypothesize that innovation activities increase bank risktaking behaviors.

Hypothesis 5. Innovation has a positive relationship with bank risk-taking in the Chinese banking industry.

(vi) Based on the capital asset pricing model (CAPM), the expected return is positively related to the expected market risk premium. Commercial banks can be perceived as investor, because they must manage assets through investments. Therefore, the CAPM can be applied to investigate the relationship between bank risk-taking and profitability. We hypothesize that there is a positive relationship between bank risk-taking and profitability.

Hypothesis 6. Risk-taking has a positive relationship with bank profitability in the Chinese banking industry.
TABLE 3: Indices of the model fit.

\begin{tabular}{lccc}
\hline$\chi^{2} / \mathrm{df}$ & RMSEA & GFI & SRMR \\
\hline 7.57 & 0.053 & 0.92 & 0.09 \\
\hline
\end{tabular}

This table reports the value of indices of model fit.

(vii) We select competition, innovation, risk-taking, and profitability as variables and investigate the cause-and-effect relationships among them. The one-on-one relationship between any two factors is supported by both empirical and theoretical works. For example, market competition directly impacts bank innovation which has an effect on risk-taking; furthermore, the risk-taking is hypothesized to be related to profitability which is affected by competition. Thus, we deduce that innovation and risk-taking play mediating role in the relationship between competition and profitability. That is to say, there is a cascading relationship among these four factors.

Hypothesis 7. There is a cascading relationship among market competition and bank innovation, risk-taking, profitability.

5.2. Results. We verify the hypotheses by applying the Analysis of Moment Structure (AMOS) software, version 21. Owing to the difference of dimensions of the observed variables, the standardized processing of original data is required. The estimated path coefficients depict the effects among variables (Figure 4).

The indices of model fit illustrated in Table 3 suggest that the SR model has an acceptable goodness of fit.

Figure 4 illustrates a complete path diagram of our model.

(i) Risk-taking-profitability: this path represents a direct effect of risk-taking on profitability (0.890). Specifically, one percent increase in risk-taking directly increases profitability by 0.890 percent. This result supports Hypothesis 6, indicating a positive relationship between risk-taking and profitability.

(ii) Innovation-risk-taking-profitability: innovation has a direct effect on risk-taking (0.471), which supports Hypothesis 5 and indicates a positive relationship between innovation and risk-taking. Moreover, innovation has both a direct and an indirect effect on profitability. The direct effect is 0.206 , and the indirect effect, which depends on the innovation-risk-takingprofitability path, is $0.419=(0.471 \times 0.890)$. Thus, the net effect of innovation on profitability, which includes both the direct and the indirect effects, is positive and equals $0.625=(0.206+0.419)$. This result supports Hypothesis 4, indicating a positive relationship between innovation and profitability.

(iii) Competition-innovation-risk-taking-profitability: competition affects innovation directly $(0.408)$, which supports Hypothesis 3 and indicates a positive relationship between competition and innovation. And competition affects risk-taking both directly and indirectly. The direct effect of competition on profitability is -0.734 , whereas the indirect effect, which depends on the competition-innovation-risk-taking 


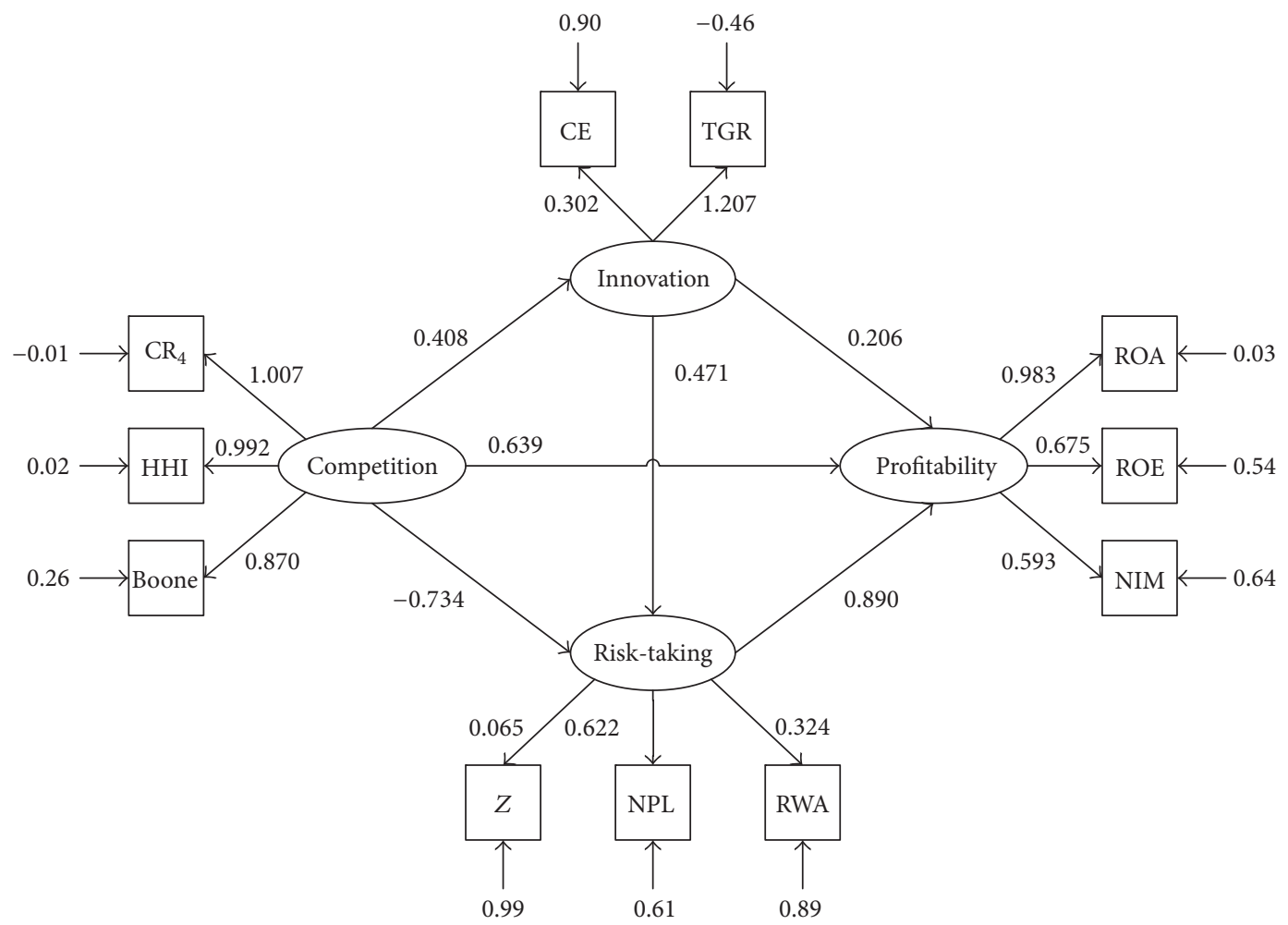

FIGURE 4: The path coefficients of variables. The exogenous latent variable, competition, is measured by the observed variables $\left(\mathrm{CR}_{4}\right.$, $\mathrm{HHI}_{\text {, }}$ and Boone index). The endogenous latent variables are innovation (measured by CE and TGR), risk-taking (measured by Z-score, NPL, and RWA) and profitability (measured by ROA, ROE, and NIM).

path, contributes $0.192=(0.408 \times 0.471)$ to the net effect. Thus, the net effect of competition on risk-taking, which includes the direct effect and all possible indirect effects, is negative and equals $-0.542=(-0.734+0.192)$. This result supports Hypothesis 2, indicating a negative relationship between competition and risk-taking. Similarly, competition affects profitability both directly and indirectly. The direct effect of competition on profitability is 0.639. The indirect effects of competition on profitability in this scenario have three paths: competition-innovation-profitability, which contributes $0.084=(0.408 \times 0.206)$ to the net effect; competition-innovation-risk-taking-profitability, which contributes $0.171=(0.408 \times 0.471 \times 0.890)$ to the net effect; and competition-innovation-profitability, which contributes $-0.653=(-0.734 \times 0.890)$ to the net effect. Thus, the net effect of competition on profitability, which consists of direct effect and all possible indirect effects, is positive and equals $0.241=(0.639+0.084+0.171-0.653)$. This result does not support Hypothesis 1 and indicates a positive relationship between competition and profitability. The SCP hypothesis is not applicable for Chinese banking, because the market power of bank primarily results from an administration monopoly rather than a natural monopoly. Moreover, the social welfare loss due to the monopoly is the other possible reason for this result.

(iv) The competition-innovation-risk-taking-profitability path of the indirect effect of competition on profitability shows that innovation and risk-taking constitute the intermediate part of this effect. This result supports Hypothesis 7 and indicates a cascading relationship among competition, innovation, risktaking, and profitability.

\section{Conclusion}

We introduce a new perspective to systematically investigate the cause-and-effect relationships among competition, innovation, risk-taking, and profitability in the Chinese banking industry. Several conclusions are obtained based on our empirical work.

(i) A positive relationship between risk-taking and profitability has been demonstrated, which indicates that the risk appetite of bank managers has significant influence on bank profitability, and the rising appetite for risk may increase the profitability of bank asset. Therefore, a balance between profitability and risktaking is vital to banks.

(ii) The net effects of innovation on both risk-taking and profitability are positive. One percent increase in 
innovation amplifies risk-taking by 0.471 percent and profitability by 0.625 percent. Thus, it is concluded that innovation more intensely affects profitability than it does risk-taking, suggesting that financial innovation should be actively supported and promoted.

(iii) Competition affects all of innovation, risk-taking, and profitability. One percent increase in competition promotes innovation by 0.408 percent and profitability by 0.241 percent, and it reduces risk-taking by 0.542 percent. This outcome shows that competition can encourage innovation, enhance profitability, and reduce risk. This result indicates that competition in the Chinese banking industry is not sufficiently intense enough. Although comprehensive reform facilitated liberalization, the monetary authority still plays a leading role.

(iv) Innovation and risk-taking constitute the intermediate part of the competition-innovation-risk-takingprofitability path, suggesting a cascading relationship among competition, innovation, risk-taking, and profitability.

\section{Disclosure}

The authors confirm that they all have checked the manuscript and have agreed to the submission.

\section{Competing Interests}

There is no conflict of interests regarding the publication of this paper.

\section{Acknowledgments}

This work was supported by the National Natural Science Foundation of China under Grants nos. 71373072 and 71501066; China Scholarship Council under Grant no. 201506135022; Specialized Research Fund for the Doctoral Program of Higher Education under Grant no. 20130161110031; and Foundation for Innovative Research Groups of the National Natural Science Foundation of China under Grant no. 71521061.

\section{References}

[1] W. S. Frame and L. J. White, "Empirical studies of financial innovation: lots of talk, little action?" Journal of Economic Literature, vol. 42, no. 1, pp. 116-144, 2004.

[2] X. M. Zhang and L. Pan, "The relationship between banking structure and relationship lending of small and medium-sized enterprise in China," Journal of Financial Research, no. 6, pp. 133-145, 2013.

[3] J. S. Bain, "Relation of profit rate to industry concentration: American manufacturing, 1936-1940," The Quarterly Journal of Economics, vol. 65, no. 3, pp. 293-324, 1951.

[4] B. M. Hassene, B. M. Kais, and K. Souad, "Regulation, market structure, risk and bank profitability in the emerging countries during the subprime crisis," Journal of Finance and Economics, vol. 3, no. 1, pp. 15-19, 2015.

[5] G. A. Bhatti and H. Hussain, "Evidence on structure conduct performance hypothesis in pakistani commercial banks," International Journal of Business and Management, vol. 5, no. 9, pp. 174-187, 2010.

[6] A. Kamau and M. Were, "What drives banking sector performance in Kenya?" Global Business and Economics Research Journal, vol. 2, no. 4, pp. 45-59, 2013.

[7] S. S. Uddin and Y. Suzuki, "The impact of competition on bank performance in Bangladesh: an empirical study," International Journal of Financial Services Management, vol. 7, no. 1, pp. 7394, 2014.

[8] Y. Tan and C. Floros, "Risk, profitability, and competition: evidence from the Chinese banking industry," The Journal of Developing Areas, vol. 48, no. 3, pp. 303-319, 2014.

[9] G. Jiménez, J. A. Lopez, and J. Saurina, "How does competition affect bank risk-taking?" Journal of Financial Stability, vol. 9, no. 2, pp. 185-195, 2013.

[10] Z. Fungáčová and L. Weill, "Does competition influence bank failures? Evidence from Russia," Economics of Transition, vol. 21, no. 2, pp. 301-322, 2013.

[11] J. H. Boyd and G. De Nicoló, "The theory of bank risk taking and competition revisited," The Journal of Finance, vol. 60, no. 3, pp. 1329-1343, 2005.

[12] G. De Nicolo and E. Loukoianova, "Bank ownership, market structure, and risk," IMF Working Papers 200, 2007.

[13] D. Martinez-Miera and R. Repullo, "Does competition reduce the risk of bank failure?" Review of Financial Studies, vol. 23, no. 10, pp. 3638-3664, 2010.

[14] J. A. Schumpeter, Capitalism, Socialism and Democracy, Harper and Row, New York, NY, USA, 1942.

[15] K. Arrow, "Economic welfare and the allocation of resources for invention," in The Rate and Direction of Inventive Activity: Economic and Social Factors, pp. 609-626, Princeton University Press, Princeton, NJ, USA, 1962.

[16] P. Aghion, C. Harris, P. Howitt, and J. Vickers, "Competition, imitation and growth with step-by-step innovation," Review of Economic Studies, vol. 68, no. 3, pp. 467-492, 2001.

[17] P. Aghion, N. Bloom, R. Blundell, R. Griffith, and P. Howitt, "Competition and innovation: an inverted-U relationship," The Quarterly Journal of Economics, vol. 120, no. 2, pp. 701-728, 2005.

[18] M. Smirlock, "Evidence on the (non) relationship between concentration and profitability in banking," Journal of Money, Credit and Banking, vol. 17, no. 1, pp. 69-83, 1985.

[19] F. Allen, E. Carletti, and R. Marquez, "Credit market competition and capital regulation," Review of Financial Studies, vol. 24, no. 4, pp. 983-1018, 2011.

[20] R. Ciciretti, I. Hasan, and C. Zazzara, "Do internet activities add value? Evidence from the traditional banks," Journal of Financial Services Research, vol. 35, no. 1, pp. 81-98, 2009.

[21] C. Weigelt and M. B. Sarkar, "Performance implications of outsourcing for technological innovations: managing the efficiency and adaptability trade-off," Strategic Management Journal, vol. 33, no. 2, pp. 189-216, 2012.

[22] İ. Akhisar, K. B. Tunay, and N. Tunay, "The effects of innovations on bank performance: the case of electronic banking services," Procedia-Social and Behavioral Sciences, vol. 195, pp. 369-375, 2015. 
[23] X. Chen, "Banking deregulation and credit risk: evidence from the EU," Journal of Financial Stability, vol. 2, no. 4, pp. 356-390, 2007.

[24] K. Schaeck and M. Cihák, "Competition, efficiency, and stability in banking," Financial Management, vol. 43, no. 1, pp. 215-241, 2014.

[25] L. Norden, C. S. Buston, and W. Wagner, "Financial innovation and bank behavior: evidence from credit markets," Journal of Economic Dynamics and Control, vol. 43, pp. 130-145, 2014.

[26] X. Hou, Q. Wang, and Q. Zhang, "Market structure, risk taking, and the efficiency of Chinese commercial banks," Emerging Markets Review, vol. 20, pp. 75-88, 2014.

[27] M. Zabarankin, K. Pavlikov, and S. Uryasev, "Capital asset pricing model (CAPM) with drawdown measure," European Journal of Operational Research, vol. 234, no. 2, pp. 508-517, 2014.

[28] M. F. Liu, X. L. Zhang, and C. Zhang, "Correlation analysis of bank diversification, performance and risk in Chinese banking industry (Article written in Chinese)," Studies of International Finance, vol. 8, pp. 59-69, 2012.

[29] J. B. Grace, "Structural equation modeling for observational studies," Journal of Wildlife Management, vol. 72, no. 1, pp. 1422, 2008.

[30] A. N. Adedeji, S. F. Sidique, A. A. Rahman, and S. H. Law, "The role of local content policy in local value creation in Nigeria's oil industry: a structural equation modeling (SEM) approach," Resources Policy, vol. 49, pp. 61-73, 2016.

[31] B. Shipley, "Confirmatory path analysis in a generalized multilevel context," Ecology, vol. 90, no. 2, pp. 363-368, 2009.

[32] T. Y. Lam and D. A. Maguire, "Structural equation modeling: theory and applications in forest management," International Journal of Forestry Research, vol. 2012, Article ID 263953, 16 pages, 2012.

[33] X. M. Fu and S. Heffernan, "The effects of reform on China's bank structure and performance," Journal of Banking \& Finance, vol. 33, no. 1, pp. 39-52, 2009.

[34] A. A. Drakos, G. P. Kouretas, and C. Tsoumas, "Ownership, interest rates and bank risk-taking in Central and Eastern European countries," International Review of Financial Analysis, vol. 45, pp. 308-319, 2016.

[35] G. E. Battese, D. S. P. Rao, and C. J. O’Donnell, "A metafrontier production function for estimation of technical efficiencies and technology gaps for firms operating under different technologies," Journal of Productivity Analysis, vol. 21, no. 1, pp. 91-103, 2004.

[36] J. W. B. Bos and H. Schmiedel, "Is there a single frontier in a single European banking market?" Journal of Banking and Finance, vol. 31, no. 7, pp. 2081-2102, 2007.

[37] J. W. B. Bos, J. W. Kolari, and R. C. R. van Lamoen, "Competition and innovation: evidence from financial services," Journal of Banking \& Finance, vol. 37, no. 5, pp. 1590-1601, 2013.

[38] M. Ariff and L. Can, "Cost and profit efficiency of Chinese banks: a non-parametric analysis," China Economic Review, vol. 19, no. 2, pp. 260-273, 2008.

[39] J. Boone, "A new way to measure competition," The Economic Journal, vol. 118, no. 531, pp. 1245-1261, 2008.

[40] R. Griffith, J. Boone, and R. Harrison, "Measuring competition," SSRN Electronic Journal, 2005. 


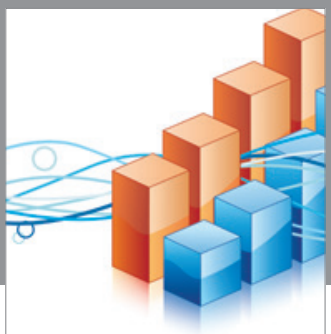

Advances in

Operations Research

vatem alat4

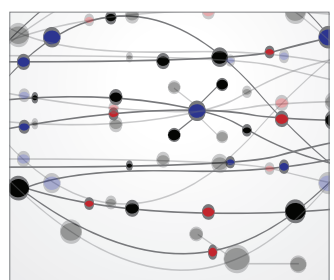

\section{The Scientific} World Journal
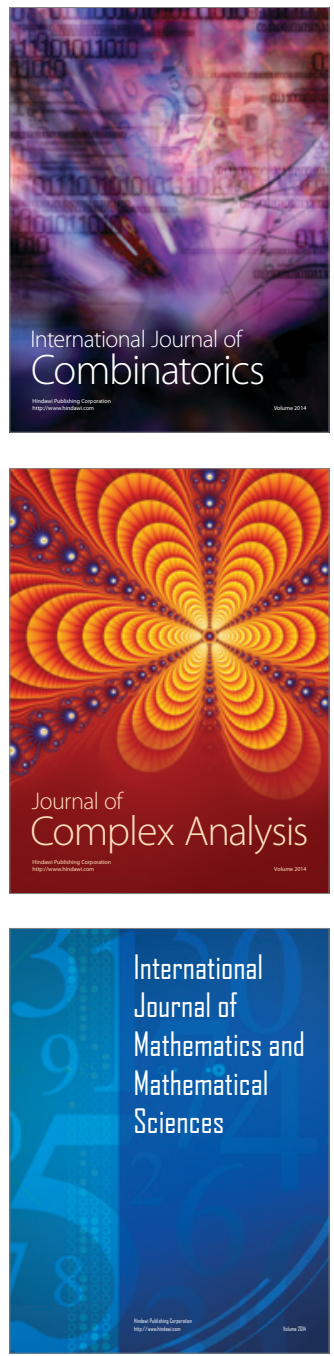
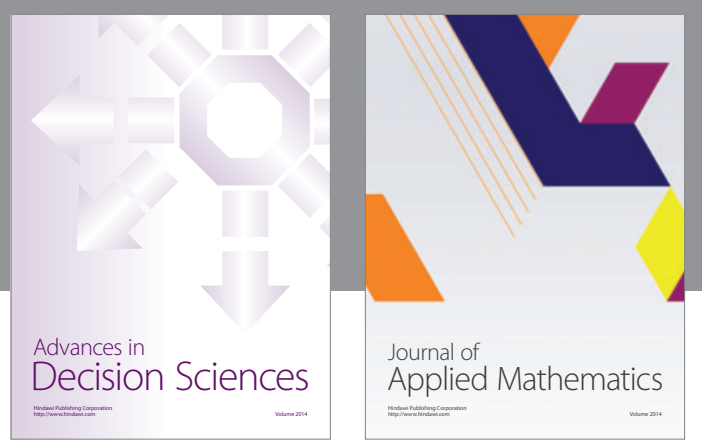

Algebra

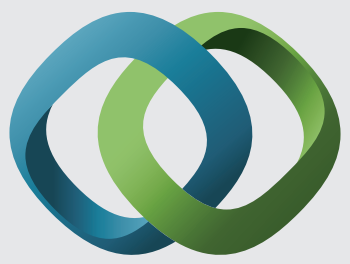

\section{Hindawi}

Submit your manuscripts at

http://www.hindawi.com
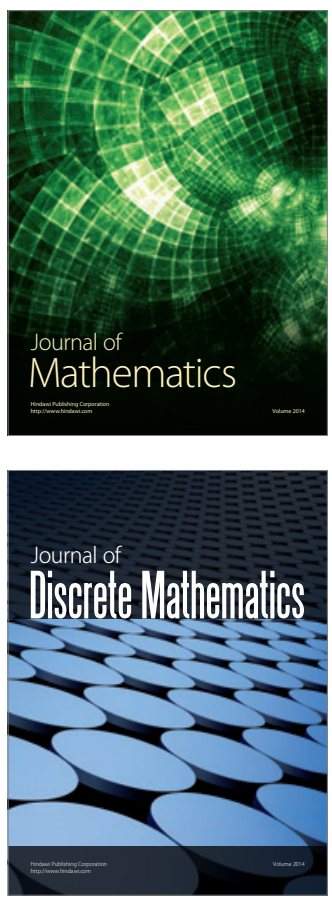

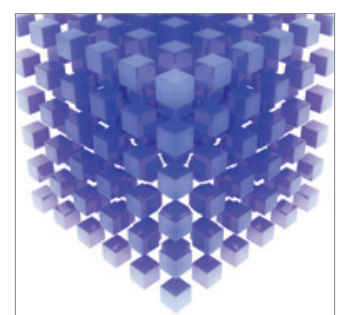

Mathematical Problems in Engineering
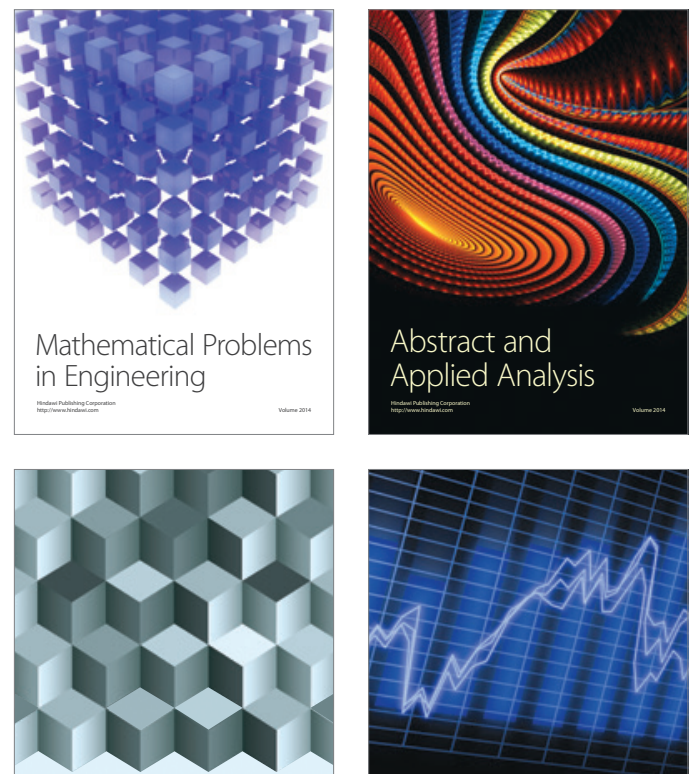

Journal of

Function Spaces

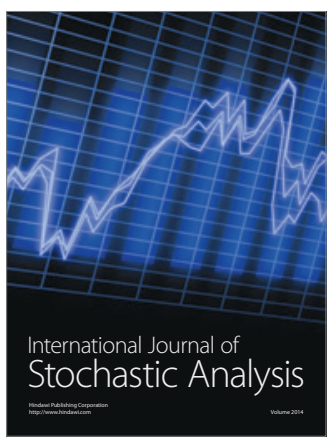

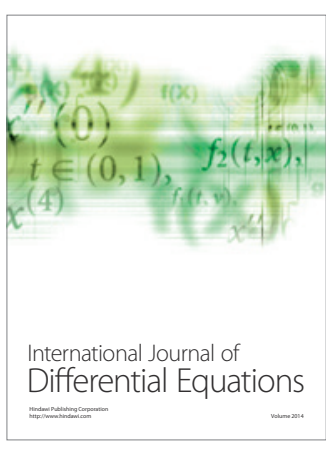
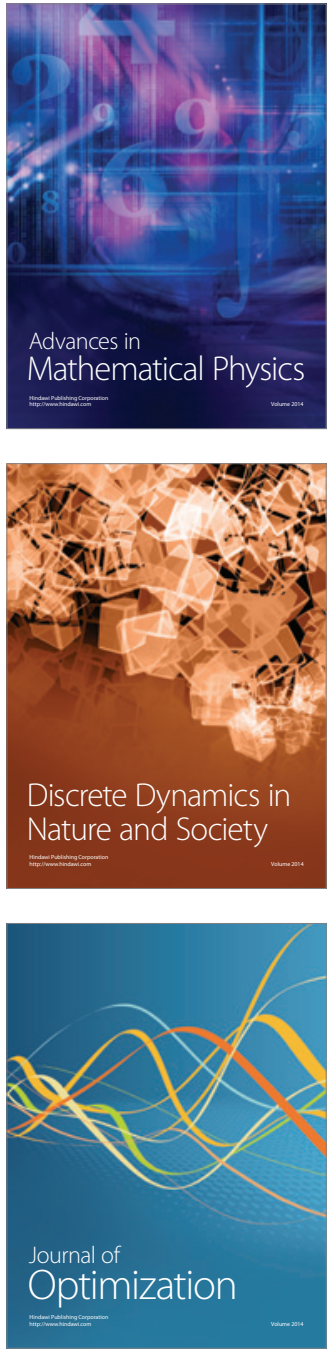